\title{
A Study of Some Aspects of Reproduction by Means of Chemical Analysis
}

\author{
BY CHRISTINE M. SPRAY \\ Medical Research Council Department of Experimental Medicine, \\ University of Cambridge
}

(Received ro Yune 1950)

Long and careful balance experiments on pregnant women have shown that more nitrogen, calcium, phosphorus and magnesium was retained by the mother than was required for the body of her newborn baby and its adnexa (Macy, Hunscher, Nims \& McCosh, 1930; Hunscher, Donelson, Nims, Kenyon \& Macy, 1932-3; Hunscher, Hummell, Erickson \& Macy, 1935; Hummel, Sternberger, Hunscher \& Macy, 1936; Coons \& Blunt, 1930; Coons \& Marshall, 1934; Coons, Schiefelbusch, Marshall \& Coons, 1935). Hunscher (1930), Macy, Hunscher, McCosh \& Nims (1930) and Donelson, Nims, Hunscher \& Macy (193I) also studied women during lactation and found that the lactating woman was often in negative calcium and phosphorus balance, but that she retained most of the nitrogen she had laid down during pregnancy.

The effects of pregnancy and lactation on the mother have been investigated in other mammals both by balance experiments and by the chemical analysis of the bodies of the mothers and their young, but the investigators have usually limited themselves to one or two constituents of the body of a single species. 'Thus the influence of reproduction upon the weight of the rat was studied by Watson (1905), Cole \& Hart (1938) and Bogart, Sperling, Barnes \& Asdell (1939-40). All agreed that during pregnancy the weight increased more than could be accounted for by the weight of the developing foetus, and that this extra weight was not all lost during lactation. Morse \& Schmidt (1944) showed, by means of nitrogen-balance experiments on pregnant and lactating rats, that all their experimental animals were storing nitrogen during pregnancy, and half of them during lactation also. The pig seems to behave in a similar way, since Evans (1929) found that sows retained far more nitrogen during pregnancy than was sufficient to meet the foetal needs. Goss \& Schmidt (1930) measured the intake and output of calcium and phosphorus by rats during pregnancy and lactation, and showed that the pregnant rat stored four or five times as much calcium as was needed for the foetuses, placentas and uterus, but that she lost this calcium again during lactation. Sherman \& MacLeod (1925) investigated the effect of pregnancy and lactation on the amount of calcium in rats, and found that the bearing and suckling of young invariably reduced the total amount of calcium in the mother. Warnock \& Duckworth (1944) analysed the bones of rats during the reproductive cycle and showed that the changes in composition were confined to the bone ends; the shafts were little affected. Zucker \& Zucker (1946) also analysed the bones and confirmed that the proportion of ash in the femurs of rats that had borne and reared young was lower than that in the 
corresponding bones of unmated females, but they found that even those females with the lowest ash had bones better calcified than those of male rats of the same age.

Smythe \& Miller (1928-9) followed the changes in the amount of iron present in the rat and found that it fell during pregnancy and rose again slowly during lactation. Widdowson \& McCance (1948) observed a large fall in the concentration and total amount of inorganic iron in the livers of pregnant rats and showed that the amount lost was approximately equal to the iron in the whole litter at birth. 'There was no increase in the mother's iron stores until she had finished suckling her young. Huggett $\&$ Widdas (1949) used ${ }^{59} \mathrm{Fe}$ to discover the amounts of iron supplied by the mother to her young, and pointed out that these are twice as great during the $2 \mathrm{I}$ days of lactation as during the $2 \mathrm{I}$ days of pregnancy. If these last few observations are to be brought into line it seems as though the mother rat absorbs far more iron from her food during lactation than during pregnancy.

Investigations of some chemical aspects of growth (Widdowson, 1950; Spray \& Widdowson, 1950) provided an opportunity of making a comparative study of the effect of reproduction on the detailed composition of three mammalian species, and the present paper presents the results obtained with the mouse, rat and guinea-pig by direct analysis of the mothers and their offspring.

\section{EXPERIMFNTAL}

\section{Animals}

The sources of the animals used in this investigation and their diets have been described by Spray \& Widdowson (1950).

Rats. Thirty-six virgin rats of similar weights and ages were divided into two equal groups. One group was mated (Spray \& Widdowson, 1950) and of these, six rats were killed for analysis at delivery, six 15 days later, at the end of the period of 'full lactation' (for definition of term see Spray \& Widdowson, 1950) and the remaining six after a recovery period of 80 days. Six rats from the second, unmated, group were analysed at each stage and served as controls. The six rats in each group at each stage were pooled for analysis. All the young belonging to the mothers that were killed at delivery were killed at birth and analysed, and also those belonging to the second six mothers when they were 15 days old. Again the animals were pooled before analysis. Large litters were reduced to eight in number at birth and the average number of young in the litters that were suckled was seven.

Twelve placentas from four rats were analysed together for nitrogen, potassium, iron, copper and zinc. Milk was obtained from six rats on the i 8 th day of lactation and was pooled for analysis. A special machine for milking small animals, described by Temple $\&$ Kon (1937) and kindly lent by $\operatorname{Dr~S.~K.~Kon,~was~used.~Analyses~were~}$ made on the fresh material.

Mice. Twenty female mice of similar weights and ages, which had not previously borne young, were used for this experiment. Ten were mated by placing one male in each cage of five females, and, of these, five were killed at delivery and five more at the end of the period of 'full lactation', i.e. 15 days after delivery. Five of the 
unmated animals were also killed on the same two occasions and analysed as controls. The young of the mothers killed at delivery were analysed and also those of the second five mothers at the age of 15 days.

Cuinea-pigs. Two female guinea-pigs were killed at delivery and analysed, and their litters were also killed at birth and analysed.

\section{Chemical methods}

The bodies of the animals were digested with hydrochloric acid and prepared for analysis as described by Venn, McCance \& Widdowson (1947) and Spray \& Widdowson (1950), and the chemical methods employed were those used by Spray \& Widdowson (1950).

\section{RESLLTS}

Rats. Table I sets out the analytical data for the rats. The figures show in a striking way the large amounts of protein, fat and minerals laid down in the maternal tissues during pregnancy in excess of those required by the foetus; more protein, fat, potassium, magnesium, copper and zinc was added to the maternal tissues than was supplied

'Table I. Composition of the bodies of mother rats and their young and of unmated control animals

\begin{tabular}{|c|c|c|c|c|c|c|c|c|}
\hline & \multicolumn{3}{|c|}{ After delivery } & \multicolumn{3}{|c|}{ At end of (full lactation)* } & \multirow{2}{*}{\multicolumn{2}{|c|}{ After recovery }} \\
\hline & \multirow[b]{2}{*}{ Control } & \multirow[b]{2}{*}{ Mother } & \multirow{2}{*}{$\begin{array}{l}\text { Young } \\
\text { (nine) } \\
\text { at birth }\end{array}$} & \multirow[b]{2}{*}{ Control } & \multirow[b]{2}{*}{ Mother } & \multirow{2}{*}{$\begin{array}{l}\text { Young } \\
\text { (seven) }\end{array}$} & & \\
\hline & & & & & & & Control & Mother \\
\hline Age (days) & 225 & 225 & 0 & 240 & 240 & 15 & 320 & 320 \\
\hline Weight (g.) & 230 & 305 & $52 \cdot 7$ & 236 & $24^{8}$ & 193 & 252 & 249 \\
\hline Total water (g.) & 130 & $174 \cdot 2$ & $45 \cdot 4$ & 137 & $166 \cdot 8$ & 147 & $148 \cdot 8$ & $1+2 \cdot 2$ \\
\hline I'otal protein (g.) & 40.4 & $49 \cdot 1$ & $5 \cdot 7$ & $4 I \cdot 5$ & 43.4 & 30.5 & $45 \cdot 1$ & $46 \cdot I$ \\
\hline 'Total fat (g.) & $51 \cdot 0$ & $72 \cdot 3$ & 0.6 & $48 \cdot 4$ & $29 \cdot 2$ & $9 \cdot 2$ & $49 \cdot 1$ & $5 x \cdot 8$ \\
\hline 'I'otal sodium (mg.) & 250 & 296 & 123 & 262 & 320 & 402 & 284 & 294 \\
\hline Total potassium (mg.) & 590 & 775 & 108 & 608 & 780 & 540 & 610 & 705 \\
\hline 'Total calcium (mg.) & 2460 & 2490 & 159 & 2660 & 2380 & 1090 & 2640 & 2640 \\
\hline Total magnesium (mg.) & $75 \cdot 9$ & $92 \cdot 6$ & $13 \cdot 1$ & $80 \cdot 6$ & $90 \cdot 3$ & 53 & $92 \cdot 0$ & $87 \cdot 1$ \\
\hline Total phosphorus (mg.) & 1450 & 1590 & 185 & 1515 & 1480 & 853 & 1520 & 1510 \\
\hline 'Iotal iron (mg.) & $12 \cdot 8$ & 12.4 & $3 \cdot 1$ & $13 \cdot 5$ & 13.0 & $5 \cdot 27$ & $I 4 \cdot 1$ & $13 \cdot 4$ \\
\hline 'Total copper (mg.) & 0.27 & $0.8_{5}$ & 0.22 & 0.26 & 0.27 & 0.91 & $0.4^{8}$ & 0.57 \\
\hline Iotal zinc (mg.) & $6 \cdot 32$ & 8.00 & $1 \cdot 27$ & $7 \cdot 34$ & 7.56 & 6.02 & $6 \cdot 75$ & -- \\
\hline
\end{tabular}

* For definition of term sce Spray \& Widdowson (1950).

to the young. The accretion of protein, for example, was $15 \mathrm{~g}$., of which $8 \cdot 7 \mathrm{~g}$. remained in the mother after delivery; and of the $2 \mathrm{I} \cdot 3 \mathrm{~g}$. of fat laid down during pregnancy only $0.6 \mathrm{~g}$. was passed on to the young. The enlargement of the uterus and mammary glands accounted for small proportions of these substances, but most must have been stored in other parts of the body. The amounts of the various constituents in the placentas are not included in the figures given in Table 1 . It has been calculated that nine placentas contained $0.6 \mathrm{~g}$. protein, $9 \mathrm{mg}$. potassium, $0.5 \mathrm{mg}$. iron, $0.05 \mathrm{mg}$. copper and $0.29 \mathrm{mg}$. zinc.

The fall in the amount of iron in the mother's body during pregnancy confirms Smythe \& Miller's (1928-9) observations. The total diminution in iron was not great, however, and on the average the animal after delivery contained only $0.4 \mathrm{mg}$. less than 
the unmated control, but since its weight was greater, the percentage of iron was reduced by approximately one-quarter.

During the 15 days after delivery there was a fall of nearly $20 \%$ in the body-weight, as the demands of lactation removed a large proportion of the 'rest materials', but at the end of this time the mother rats still weighed more than the controls. Of the $57 \mathrm{~g}$. body-weight lost, $43 \mathrm{~g}$. were accounted for by loss of fat. 'The rat's milk which was analysed contained $14.2 \%$ fat, which is approximately twice as much as in sow's milk (Braude, Coates, Henry, Kon, Rowland, Thompson \& Walker, I947) and four times as much as in human or cow's milk per $100 \mathrm{ml}$. During the $\mathrm{I}_{5}$ days when the young received no food other than mother's milk, the total fat in the litter increased by about 8.6 g. compared with $0.6 \mathrm{~g}$. during the $2 \mathrm{I}$ days of gestation. Rat's milk is also rich in protein ( $10 \mathrm{~g} / 100 \mathrm{~g}$. milk), and the rapid gains in weight which the young made during the first 15 days of extra-uterine life were based largely upon their retention of protein. Meanwhile, the mother lost about $6 \mathrm{~g}$. of her own body protein.

The demands for calcium and phosphorus during lactation were very great, the total amounts of these elements in seven young rats increasing in 15 days from 124 to I $090 \mathrm{mg}$. and from $\mathrm{I} 54$ to $853 \mathrm{mg}$. respectively. Concentrations in the milk were high (384 mg. calcium and $226 \mathrm{mg}$. phosphorus/100 g. milk) and the mother rat lost not only the stores of calcium and phosphorus built up during pregnancy but also appreciable additional amounts, especially of calcium, from her own tissues. The loss of magnesium $(24 \mathrm{mg} / \mathrm{1} 00 \mathrm{~g}$. milk) was proportionately not so high and the mother rat at the end of $I_{5}$ days' lactation still contained more of this element than the control.

The total amount of iron in the mother rats was slightly greater after lactation than it had been at delivery and was not far below that of the controls, although the amount of iron in the latter had increased. This is of considerable interest in view of the fact that Cox \& Mueller (1937) claimed that the concentration of iron in rat's milk is ten times as great as in cow's milk and three-and-a-half times as great as in human or sow's milk. The bodies of rats that had suckled a family contained less fat and more fat-free material than those of the controls or of the rats that had just given birth, and the concentration of iron in the fat-free portion of the body was considerably lower: $5.9 \mathrm{mg}$. $/ \mathrm{r} 00 \mathrm{~g}$. for the mother at the end of lactation against $7.6 \mathrm{mg}$. for the control.

'The amount of copper contributed by the rat's tissues during lactation $(0.72 \mathrm{mg}$.) roo g. milk) was exactly equal to the amount stored during gestation, and very similar to the amount retained by the young. The zinc concentration in the milk $(5.54 \mathrm{mg}$.) $100 \mathrm{~g}$.) was high, and a considerable proportion of it must have been used for the growth of hair by the young (Spray \& Widdowson, 1950), but the loss from the maternal tissues was only small.

After a period of recovery of 80 days, the weights and the chemical composition of the mother rats resembled those of the controls. When lactation came to an end, the fat deposits were built up again, the protein increased slightly and the mineral concentrations returned to normal. The only striking difference between the two groups of rats at 320 days was in the concentrations of inorganic iron in the livers (Widdowson \& McCance, 1948). Zucker \& Zucker (1946) found that virgin rats had more bone ash than females that had produced two to eight litters, even 185 days after the weaning 
of the last litter. This is apparently not necessarily so if only a single litter has been reared.

Mice. The results of an experiment on the mouse similar to that described on the rat are given in Table 2. The general effect of pregnancy and lactation on the composition of the mouse was very similar to the effect on the rat, but the mouse donated

'Table 2. Composition of the bodies of mother mice and their young and of unmated control animals

Weight (g.)

Total water (g.)

Total protein (g.)

Total fat (g.)

Total sodium (mg.)

I'otal potassium (mg.)

Total calcium (mg.)

Total magnesium (mg.)

Total phosphorus (mg.)

Total iron (mg.)

Total copper (mg.)

Total zinc ( $\mathrm{mg}$.)

$\begin{array}{cccccc}\text { Young } & & \text { At end of 'full lactation' } \\ \text { Control } & \text { Mother } & \begin{array}{c}\text { After delivery) } \\ \text { at birth }\end{array} & \text { Control } & \text { Mother } & \begin{array}{c}\text { Young } \\ \text { (six) }\end{array} \\ 26.6 & 38.6 & 10.85 & 27.1 & 33.7 & 56.0 \\ 19.63 & 27.38 & 9.03 & 19.92 & 25.19 & 42.4 \\ 4.44 & 7.16 & 1.36 & 4.62 & 5.62 & 9.3 \\ 1.48 & 2.76 & 0.22 & 1.49 & 1.86 & 2.7 \\ 35 & 51 & 24.0 & 38 & - & 82 \\ 79 & 104 & 29.1 & 79 & 125 & 150 \\ 284 & 343 & 36 & 292 & 230 & 318 \\ 10.7 & 10.9 & 3.6 & 10.9 & 9.5 & 17.2 \\ 174 & 216 & 36 & 181 & 171 & 258 \\ 2.24 & 2.21 & 0.71 & 2.48 & 3.17 & 2.46 \\ 0.22 & 0.11 & 0.07 & 0.23 & 0.14 & 0.27 \\ 1.18 & 1.71 & 0.50 & 1.38 & 1.20 & 2.71\end{array}$

* For definition of term see Spray \& Widdowson (1950).

much greater proportions of her own substance to her offspring, e.g. the fat, protein and calcium contents of the mouse litter at birth were respectively 8,19 and 1 I $\%$ of the total amounts in the maternal tissues. Corresponding figures for the rat were 0.8 , I 2 and $6 \%$. Even so, the mouse was able to deposit more fat, protein, calcium, phosphorus and zinc in her own tissues than the foetuses acquired during gestation. The iron concentration was reduced by approximately the same proportion as in the rat, and for some not obvious reason, the mouse went into negative copper balance.

The first 15 days of lactation produced a fall in body-weight of less than $13 \%$, compared with $20 \%$ in the rat. The loss of fat was also smaller, and the lactating mouse still contained appreciably more of it than the control. The composition of mouse's milk is not known, but the young mouse grows at an even more rapid rate than the rat, so it must be of high calorific value. The mother mouse was able to increase the weight of iron in her body during lactation, and the concentration as well as the total were greater than in the control of the same age.

Guinea-pigs. The results obtained on two guinea-pigs at delivery and their litters are shown in Table 3. The guinea-pig is a remarkable animal in that the female can produce a litter weighing half as much as herself. The high proportion of fat in the newborn guinea-pig and the degree of calcification of its bones have already been discussed (Widdowson, 1950). The present findings bring out clearly the enormous demands on the mother during pregnancy if she is to produce a litter of young, not only so heavy in relation to her own weight, but also of this chemical composition. The young guinea-pigs received much greater quantities of every constituent in pro- 
Table 3. Composition of the bodies of mother guinea-pigs and their young

$\begin{array}{lccc}\text { Mother after } & \text { Young (three) } \\ \text { delivery } & \begin{array}{c}\text { Amounts in young } \\ \text { as percentage of } \\ \text { amounts in mother } \\ \text { after delivery }\end{array} \\ \text { Weight (g.) } & 514 & 240 & 47 \\ \text { Total water (g.) } & 400 & 170 & 43 \\ \text { Total protein (g.) } & 77 & 36 & 47 \\ \text { Total fat (g.) } & 19 & 24 & 126 \\ \text { Total sodium (mg.) } & 772 & 372 & 48 \\ \text { Total potassium (mg.) } & 1370 & 646 & 47 \\ \text { Total calcium (mg.) } & 5320 & 2445 & 46 \\ \text { Total magnesium (mg.) } & 167 & 89 & 53 \\ \text { Total phosphorus (mg.) } & 3155 & 1600 & 51 \\ \text { Total iron (mg.) } & 44 & 14.4 & 33 \\ \text { Total zinc (mg.) } & 11 \cdot 6 & 7 \cdot 5 & 65\end{array}$

portion to the total amounts in the mother's body than the young rats or mice, e.g. the bodies of the newborn rats and mice contained less than one-tenth as much fat as those of their mothers, but the guinea-pig mother deposited more fat in her foetuses than she herself had. Unfortunately, no unmated control animals were analysed so there is no direct evidence as to whether nitrogen, fat and minerals were added to the guinea-pig's own body during pregnancy. If the teleological explanation is accepted that the 'rest material' is a provision for the demands of lactation, one would not expect the guinea-pig to increase her own body substance very much, since her progeny can take food other than milk from the ist day of life. If Tables $I$ and 3 are inspected it will be noted that the litters of mice at the end of full suckling contained larger amounts of nearly all constituents than their mothers; the young rats contained only a little less of most substances than their mothers by the time they were 15 days old. If guinea-pigs grew at the same rate as rats during the first 15 days of their lives and depended upon their mother's milk for doing so, they would have to consume about twice as much protein, fat and minerals as their mothers contained.

\section{DISCLSSION}

The results of the present investigation support those of previous work on rats, and show that in mice also the mother animals retain and store far more nitrogen, fat and most mineral elements during pregnancy than their foetuses and adnexa contain. Work previously recorded in the literature makes it clear that the human mother behaves in a similar way. Iron is an exception in that the bodies of mother rats and mice contained slightly less of this element after delivery than those of control rats and mice of the same age, and Coons et al. (1935) showed, as a result of iron-metabolism studies in human mothers, that women did not retain enough iron during pregnancy to meet the needs of the developing foetus.

There are, however, interesting species differences, and from a consideration of the composition of the guinea-pig and her litter at birth it seems extremely unlikely that much storage of 'rest material' can take place in this animal, and it should not be assumed that pregnancy is invariably associated with this process. We are far from 
understanding the subtle variations between different specics which cause one, that lactates abundantly, to lay in a 'store' during pregnancy, and allows another, that does not require to produce much milk, to pass on more to her foetuses before they are born.

\section{SUMMARY}

1. During pregnancy rats stored more protein, fat, potassium, zinc and copper in their own bodies than they transmitted to the foetuses and adnexa. They also retained more calcium and phosphorus than non-pregnant animals.

2. During lactation the mothers lost part of the protein they had retained during pregnancy and more than all the fat, calcium and phosphorus.

3. Mice reacted to pregnancy and lactation similarly to rats, but they lost notably less fat after delivery.

4. In relation to the same substances in their own bodies, guinea-pigs transmitted more protein and far more fat, calcium, phosphorus and other elements to their young during pregnancy than did rats or mice, but correspondingly less during lactation.

\section{REFERENCES}

Bogart, R., Sperling, G., Barnes, L. L. \& Asdell, S. A. (1939-40). Amer. F. Physiol. 128, 355.

Braude, R., Coates, M. E., Henry, K. M., Kon, S. K., Rowland, S. J., Thompson, S. Y. \& Walker, D. M. (1947). Brit. F. Nutrit. I, 64 .

Cole, H. H. \& Hart, G. H. (1938). Amer. F. Physiol. 123, 589.

Coons, C. M. \& Blunt, K. (1930). F. biol. Chem. 86, r.

Coons, C. M. \& Marshall, G. B. (1934). F. Nutrit. 7, 67.

Coons, C. M., Schiefelbusch, A. T'., Marshall, G. B. \& Coons, R. R. (1935). Bull. Okla. agric. Exp. Sta. no. 223.

Cox, W. M. \& MTucller, A. J. (1937). F. Nutrit. 13, 249.

Donclson, E., Nims, B., Hunscher, H. A. \& Macy, I. G. (1931). F. biol. Chem. 91, 675.

Evans, R. F. (1929). F. ayric. Sci. 19, 752.

Goss, H. \& Schmidt, C. I. A. (1930). F. biol. Chem. 86, +17.

Huggett, A. St (צ. \& Widdas, W. F. (1949). Y. Physiol. 110, 386.

Hummel, F. C., Sternberger, H. R., Hunscher, H. A. \& Macy, I. G. (1936). F. Nutrit. r1, 235.

Hunscher, H. A. (1930). F. biol. Chem. 86, 37.

Hunscher, H. A., Donelson, E., Nims, B., Kenyon, F. \& Macy, 1. G. (1932-3). Y. biol. Chem. 99, 507.

Hunscher, H. A., Hummell, F. C., Erickson, B. N. \& Macy, I. G. (1935). F. Nutrit. 10, 579.

Macy, I. G., Hunscher, H. A., McCosh, S. S. \& Nims, B. (r930). F. biol. Chem. 86, 59.

Macy, I. G., Hunscher, H. A., Nims, B. \& McCosh, S. S. (1930). F. biol. Chem. 86, 77.

Morse, I. MI. \& Schmidt, C. I. A. (1944). Proc. Soc. exp. Biol., N.Y., 56, 57.

Sherman, H. C. \& Macleod, F. L. (1925). J. biol. Chem. 64, 429.

Smythe, C. V. \& Miller, R. C. (1928-9). F. Nutrit. 1, 209.

Spray, C. MI. \& Widdowson, E. M. (1950). Brit. F. Nutrit. 4, 332.

Temple, P. L. \& Kon, S. K. (1937). Biochem. F. 31, 2197.

Venn, J. A. J., McCance, R. A. \& Widdowson, E. M. (1947). F. comp. Path. 57, 314.

Warnock, G. M. \& Duckworth, J. (1944). Biochem. Y. 38, 220.

Watson, J. B. (1905). F. comp. Neurol. 15, 514.

Widdowson, E. M. (1950). Nature, Lond., 166, 626.

Widdowson, E. M. \& McCance, R. A. (1948). Biochem. F. 42, 577.

Zucker, T. F. \& Zucker, L. M. (1946). Amer. F. Physiol. 146, 585. 